Historic, Archive Document

Do not assume content reflects current scientific knowledge, policies, or practices. 



\section{Burnett Brothers}

\section{OFFERS \\ 200,000 Pot-Grown Strawberries}

Q

OTGROIN strawberry plants are much superior to the ordinary ground layers usually sold, as there is no loss of fine roots in taking them up. They can be transplanted at any season with scarcely any check to their growth. The sooner pot-grown plants can be set out after June 1st, the larger they will grow and the more they will produce the next spring. ile only offer rarieties that are considered the best of existing sorts.

Those marked "P" have pistillate or imperfect florrers and must be planted near perfect-flowering kinds in order that the flower may fertilize. Varieties not so marked are perfect-flowering and can be planted alone.

\section{Brief Directions for Culture}

Strawberries require rich, well-tilled soil. The plants should be set 15 inches upart, in rows $2 \mathrm{ft}$. apart. 100 plants will plant 4 rows $30 \mathrm{ft}$. long, if set above distance apart. For horse cultivation set plants $2 \mathrm{ft}$. apart in rows $3 \mathrm{ft}$, apart. 7.260 plants at this distance will plant an acre. Firm the plants well in the soil, keeping them thoroughly cultirated and cut off all runners. About the middle of December, cover bed with salt-meadow hay. straw or leaves. In April, as soon as the plants show indications of growth, push the covering away from the plants to allow them to come through The mulching protects the plants from cold in the winter and heat in the summer, keeping the fruit clean and prevents the growth of weeds.

\section{American Everbearing or Fall-Fruiting Varieties of Recent Introduction $\$ 5.00$ Per 100; $\$ 1.25$ Per Doz.}

\section{AMERICUS}

A new seedling of thrifty growth; good yielder and shipper; fruit of nedium size; extensively advertised and has given satisfaction wherever tried.

\section{PROGRESSIVE}

One of the best fall-bearing sorts; strong grower; berries round, deep crimson. It begins to ripen with second earlies and plants yield vast quantities of fine berries. keeping on bearing fruit until late fall.

\section{SUPERB}

A healthy grower, makes plants freely, yields fruit only on parent plants. The berries are a rich blood red from surface to centre.

\section{New American Varieties of 1916 KELLOGG'S PREMIER}

The fruit begins ripening with the earliest varieties and continues until the latest varieties are at their best. The berries are larger than those of any other early variety. Fruit is deeply and richly colored and very firm, which makes it a fine shipper. Foliage is light green, grows tall and spreads completely over its load of fruit, which protects the berries from the sun. It is a good runner and easily handled in the fruiting bed. $\$ 1.25$ per dozen, $\$ 5.00$ per 100 . 


\section{PENNELL}

A vigorous grower and sure cropper: iruil zs lanse and fine when given

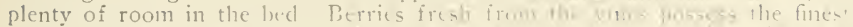

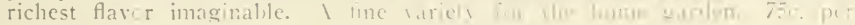
dozen, $\$ 4.00$ per 100 .

\section{Best of Laxton's English Varieties BEDFORD CHAMPION}

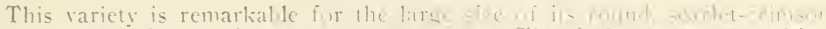

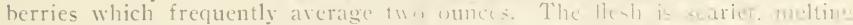

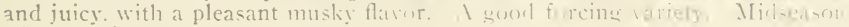
75c. per dozen.

\section{GIVON'S LATE PROLIFIC}

A handsome late variety of exceptional meril; and.. weatow ataped irui flesh firm. of richost flavor: a vory free cropper Lalest of all 750 . pu. diozen.

\section{LAXTON}

This is one of the finest of the English lurris and is mass mamberiul i.w

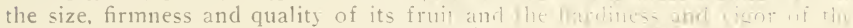
plants. Not recommended for forcing. Early $i=0$, in tazcn

\section{ROYAL SOVEREIGN}

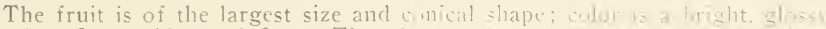
scarlet; flesh white and firm. The plants are strong ganwer ard prorlms large crops of herries. Unequaled for early forcing. $\%$ c. per iozen.

\section{STANDARD VARIGTIES \\ Price 60 cents per doz., $\$ 3.50$ per 100 , except where noted for the newer varieties. ABINGTON}

Plants are of rigorous habit, with clean. healthy folias, lerme are wh large and attractive. Mid-season

\section{AROMA}

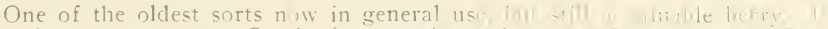

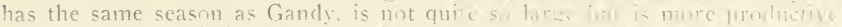

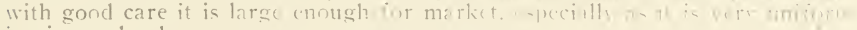
in size and rnlor

\section{AUGUST LUTHER}

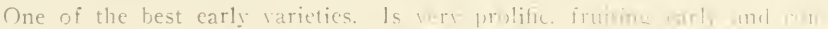
inuing until practically every herry rest a a in size and shape; dark red; firm. St.no per 100 )

\section{BARRYMORE (New)}

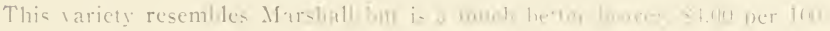

\section{BAYSIDE}

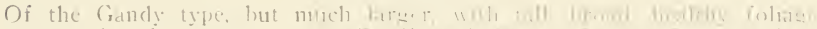

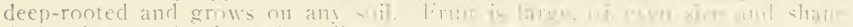
dark, glussy rerl. of goorl r|11ilit.

\section{BEDER WOOD}

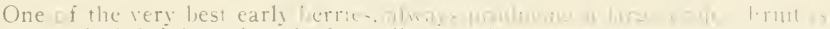
large. conical, bright red, and of excellent yuthlus 


\section{BRANDYWINE}

Berries are large, firm and solid, excellent in quality, with fine aromatic flavor. A vigorous grower, succeeding on any soil. Mid-season to late.

\section{BUBACH (P)}

The most popular of all large strawberries. Plant is very productive, completely covering ground about it with berries which are roundish, slightly flattened. Mid-season.

\section{CHESAPEAKE}

One of the best strawberries grown, all things considered. It is very large, of fine form, as late as Gandy and in flavor ranks with "Marshall" and "Wm. Belt.” $\$ 4.00$ per 100 .

\section{CHIPMAN}

Fruit is very large, with large, green caps; a very good, firm berry, ripening early; a heavy cropper. $75 \mathrm{c}$. per doz., $\$ 4.00$ per 100 .

\section{CLIMAX}

Plants strong, hardy and enormously productive. Berries are large, nearly round, very firm; valuable for long shipment. Extra early. $\$ 4.00$ per 100.

\section{CLYDE}

Large berries of excellent flavor; very firm. Plants healthy, vigorous and productive. Early, $\$ 4.00$ per 100 .

\section{COMMONWEALTH}

A valuable extra large variety. Fruit is large, smooth, dark red and juicy, of excellent quality.

\section{CORSICAN}

Large and uniform in shape, bright red color; medium late.

\section{EARLY JERSEY GIANT}

Very early. Berries very large, scarlet-crimson; color all over at once; have mild, wild strawberry flavor. Plants are strongly rooted, large and of vigorous growth. $75 \mathrm{c}$. per dozen, $\$ 4.00$ per 100 .

\section{EARLY OZARK}

A very early berry of fine flavor; as sweet as Aroma.

\section{EXCELSIOR}

Its tall, thick foliage protects blossoms from frosts. a good point for such an extra early variety. Fruit is large, handsome and firm.

\section{FENDALL (P)}

A seedling from Wm. Belt which partakes of all the good qualities of its parent, but is far superior in flavor. Mid-season to late. $\$ 4.00$ per 100 .

\section{FIRST QUALITY}

The plants are very large, strong, upright growers, with healthy, dark green foliage. In productiveness, it ranks with Sample and other well known varieties. Fruit is large, uniform in shape, colors well, frm enough for a commercial variety and of good quality.

\section{GANDY}

The standard late variety by which all other late varieties are compared. A strong, compact grower with large, firm lerries of finest flavor. Still keeps up with Chesapeake in size and production

\section{GIANT RUBY (P)}

Very productive, vigorous plants; immense berries of excellent flavor, ripening soon after the early sorts and continuing to bear until others are gone. $\$ 4.00$ per 100 . 


\section{GIBSON}

Commences to ripen with Dunlap and continues well into the season of late berries; large, healthy leaves; a very good keeper.

\section{GLEN MARY}

Makes strong, sturdy plants which are amply able to mature their immense load of fruit; a superb variety which unites large size. great productiveness and good quality. We can recommend this variety to give entire satisfaction.

\section{HAVERLAND (P)}

A standard variety that is universally praised. It succeeds on all kinds of soil, and seems to be the least affected by frost, often producing a full crop of perfect fruit when other varieties are badly damaged. Medium in season. very productive, large to very large, and holds up in size to the last picking. It is long in shape, gradually tapering, and light scarlet in color. $\$ 4.00$ per 100 .

\section{HELEN DAVIS}

Noted for its productiveness and very long fruiting season; yields enormous crops of very large berries, many of them averaging as large as medium sized hen eggs; foliage tall and green; a good plant maker. $75 \mathrm{c}$. per dozen, $\$ 4.00$ per 100 .

\section{HERITAGE}

A long-season variety, bearing from early to late; berries are very large and firm.

\section{HUB}

Fruit is large, smooth, firm, dark, glossy red; berries shine as if varnished. Plants are very productive. $75 \mathrm{c}$. per dozen, $\$ 4.00$ per 100 .

\section{HUNDRED DOLLAR}

A valuable mid-season variety. Plant is strong grower, berries very large of bright scarlet color, mild, sweet and luscious. $75 \mathrm{c}$. per dozen, $\$ 4.00$ per 100 .

\section{HUNN (P)}

An extra late variety; very productive. Berries are extra large, deeply zolored; flesh hrm, of excellent flavor.

\section{JESSIE}

A fancy strawberry of highest quality; an extra heavy yielder and good pollenizer.

\section{JOE JOHNSON}

A wonderful new strawberry, ripening about the same time as Chesapeake; it makes a fine bed of plants, while Chesapeake is rather a shy plant maker; berry is very large and one of the best flavored, perfect for table and canning purposes.

\section{KEVITT'S WONDER}

One of the very best strawberries, that is, covering every point of merit. of high rank, exceedingly beyond the limit for productiveness, firmness of color, flavor and shape of berries, it is pronounced the ideal strawberry. It contains but very little acid. has very few seeds, and is mild and sweet. The plants yield a heavy load of fruit. 75c. per dozen, $\$ 4.00$ per 100 .

\section{KLONDYKE}

Berries uniform and shapely, dark red and very handsome; a good yielder.

\section{LADY THOMPSON}

Berries medium in size. of very rich flavor; very productive, a thrifty grower and great drought resister. 


\section{LESTER LOVETT}

One of the best extra late berries offered, fruiting two weeks after nearly all the other late sorts. Berries are large, conical in shape, and uniform.

\section{LONGFELLOW}

Its season is early to late. The fruit is long and of perfect form, dark red, colored through to center; flavor is rich, mild and sweet. An ideal pollenizer of pistillates of early and mid-season sorts.

\section{McALPINE}

Late, a heavy yielder, berries are large and full to the very last pickings. $\$ 5.00$ per $100 ; \$ 1.25$ per dozen.

\section{McKINLEY}

For large size, beauty, great productiveness and high quality, it stands high among strawberries. A most remarkable variety, ripening in mid-season.

\section{MANHATTAN}

This is a New Jersey berry of large production; berries are large and of fine sweet flavor; juicy. $\$ 4.00$ per 100 .

\section{MARSHALL}

One of the richest flavored strawberries grown. Always the leader. Dark, crimson when fully ripe, and of large size. A superb variety. Mid-season.

\section{MASCOTT}

A new late sort of unusually large size and great productiveness. Season same as Gandy, lasting longer and usually producing a much better crop of equally good berries. Has been found to do well on land too dry for Gandy. $\$ 4.00$ per 100 .

\section{MICHEL'S EARLY}

One of the earliest perfect-flowering sorts in cultivation that will produce a full crop. A robust grower; will not rust or mildew; yields large, handsome berries of excellent flavor.

\section{MISSIONARY}

Somewhat resembles the Klondyke, having same medium early season and equally high color. It is to be recommended as the best berry of its class and season. Has all the good market advantages of Klondyke with larger average size, a very important matter at the season. Very productive. $\$ 4.00$ per 100 .

\section{NEW HOME}

As late and as large as Gandy. Fruit of bright red color, uniformly large. A good keeper and shipper. $\$ 4.00$ per 100.

\section{NEW YORK}

Berries are very large, some rather pointed, while others are thick and broad; dark scarlet with no green sides or tips; quality is good. Plants grow large and stalky. Mid-season.

\section{NICK OHMER}

A superb variety for the home table. as it is a good grower, free from rust and bears heavy crops of large, dark glossy red berries, highly colored all the way through, and of superior flavor. Medium to late.

\section{OHIO BOY}

Plants are vigorous and very productive; fruit is large, dark red and a good shipper. It begins to ripen with the late mid-season varieties and continues in bearing until the late varieties are gone.

\section{OOM PAUL}

Fruit is very large, sometimes flattened; color dark red both inside and out; flesh is firm and of good quality. Valuable for home or commercial purposes. Mid-season to late. 


\section{PARSON'S BEAUTY}

A good, healthy grower and an immense cropper, bearing fine berries from early until late in the season.

\section{PRIDE OF DELAWARE}

A large, firm, evenly colored berry, plants holding the fruit up well from the ground; ripens a few days before Gandy.

\section{REWASTICO}

Color is rich, deep. cardinal red, which penetrates the berry through and through. Very productive; a healthy, vigorous grower. Fruit of uniform, large size. The only real competitor Chesapeake ever had and in some respects, it even surpasses that most popular variety.

\section{RYCKMAN}

Its great size and productiveness, thrifty growth and delicious flavor make it one of the most valuable berries ever grown. It is noted as an extremely valuable variety for poor soils. Mid-season.

\section{SAMPLE (P)}

A large, round, dark crimson berry of extra good quality. Late bearer. $\$ 4.00$ per 100 .

\section{SCOFIELD}

On account of its extra large size berries, everyone admircs it. Flavor rich and aromatic. Strong foliage with thick broad leaves. $\$ 400$ per 100 .

\section{SENATOR DUNLAP}

Fruit is large, dark red in color, and has very rich flavor. Plants are exceedingly prolific. Medium to late.

\section{SHARPLESS}

Thrives better in rich, strong soil. Berries are very large, irregular in shape, moderately firm and of good quality. One of the best for table use. Mid-season.

\section{STEVEN'S LATE}

A new variety, fruiting very late in the season, yielding large crops of fine berries. $\$ 4.00$ per 100 .

\section{SUCCESS}

It is the best of the large. early varieties that we have fruited. The plant is exceptionally vigorous and prolific. Berries are firm, bright crimson.

\section{SUPERIOR}

An early variety of good growth, with dark red berries; free from disease; does well on any soil.

\section{THREE W'S}

A popular mid-season variety; large fruit of fine quality.

\section{TOWNSEND'S LATE}

Season just ahead of Gandy; a strong, hardy grower, making plenty of deep rooted plants. Fruit very large, round and of uniform size; deep red to the center, no green tips; fine, mild flavor.

\section{TWILLEY}

A mid-season variety of good quality and a healthy grower.

\section{WARREN}

The fruit is very large and handsome; it is one of the first to sell at a good price. The plants are good growers, extra large, with thick, dark green foliage. 
WARFIELD

A well known standard canning berry; plants are very vigorous and productive. Fruit large, nearly round, dark, glossy red, firm and of good quality.

\section{WM. BELT}

Berries are always of large size and good quality; flesh is solid, meaty, deep crimson in color. It begins to ripen quite early, continuing until almost the close of the season, and the last berries are handsome, large and full flavored.

\section{UNCLE JIM or DORNAN}

Mid-season to late; a healthy grower, doing well in dry weather.

\section{SPECIAL COLLECTINS \\ For the Family Garden}

COLLECTION A.

COLLECTION B. 100 Early, 100 Mid-season and 100 Late. Price $\$ 10.00$

COLLECTION C. 150 Early, 150 Mid-season and 200 Late. Price $\$ 17.00$

COLLECTION D. 350 Early, 350 Mid-season and 300 Late. Price $\$ 32.50$

\section{CELEERY PLANTIS \\ We Can Supply All Varieties In Season}

We make a specialty of Grass Seed Mixtures and Supply many of the largest estates in the country $\quad \therefore \quad \therefore$

Write for our illustrated booklet. How to make- How to keep a perfect lawn $\quad \therefore \quad \therefore \quad \therefore \quad \therefore \quad \therefore$

Also for our illustrated Fall Bulb Catalogue and Perennial List.

\section{BURNETT BROTHERS \\ $\because \quad$ S e ed $\mathrm{s}$ m e $\mathrm{n}$}

98 CHAMBERS ST. NEW YORK 